\title{
An update on the potential for male contraception: emerging options
}

This article was published in the following Dove Press journal:

Open Access Journal of Contraception

10 April 2013

Number of times this article has been viewed

\author{
Deborah A Garside' \\ Ayman Gebril ${ }^{2}$ \\ Manal Alsaadi ${ }^{2}$ \\ Natalie Nimmo ${ }^{2}$ \\ Alexander B Mullen² \\ Valerie A Ferro ${ }^{2}$ \\ 'Imperial College London, Faculty \\ of Medicine, London, ${ }^{2}$ University of \\ Strathclyde, Strathclyde Institute of \\ Pharmacy and Biomedical Sciences, \\ Glasgow, UK
}

\begin{abstract}
The human population continues to grow and is estimated to rise to 10.1 billion by the end of the century. Therefore, there is still an unmet need for safe and highly effective contraceptive options for both men and women. Current options available to men include withdrawal, condoms, and vasectomy. Methods in development fall into two categories: hormonal and nonhormonal. This review will provide an overview of the testosterone combinations and immunocontraception of hormonal targets. Nonhormonal immunocontraception of sperm proteins will also be examined, together with the use of agents to disrupt other sperm-associated targets and pathways. The categories focused on include epididymal proteins, testicular kinases, epigenetic reader proteins, opioids, lonidamine derivatives, retinoic acid, microRNAs associated with spermatogenesis, and plant extracts. Considering these developments, the number of options available to men is likely to increase in the near future.
\end{abstract}

Keywords: hormonal, immunocontraception, nonhormonal contraceptives

\section{Introduction}

Despite the number of contraceptive methods available, unintended pregnancies still occur worldwide. This is in part due to a lack of appreciation of the unintended pregnancy risk, particularly among teenagers in developed countries where contraception is readily available. However, there is still a worldwide unmet need for more affordable, effective, and practical contraceptives, indicating that further technological advancements or innovations to existing products are required. ${ }^{1}$ The oral contraceptive pill for women has had significant impact on societal dynamics and socioeconomic benefits, while the development of male contraceptive options equivalent to female products has proven an elusive goal. ${ }^{2}$ The main reason for this is that while sperm production can be controlled by the administration of sex steroids, there is also a decrease in testosterone that requires "add-back" therapy. ${ }^{3}$ Nevertheless, while the human population continues to rise - from 7 billion people in 2011 to an estimated 10.1 billion by the end of the century ${ }^{4}$ - there is still an unmet need for safe and highly effective contraceptive options for both men and women. Further, expansion of available products allows both partners to share family planning responsibility. Better contraceptive availability and use also has an impact on reducing maternal deaths through preventing high-risk pregnancies and unsafe abortions. ${ }^{5}$ This review focuses on emerging options in male contraception and looks at potential future directions.
Correspondence: Valerie A Ferro University of Strathclyde, Strathclyde Institute of Pharmacy and Biomedical Sciences, 16 I Cathedral Street, Hamnett Wing, Room 3.04, Glasgow, G4 ORE, UK Tel +44 I4I 5483724

Fax +44 I4I 5482562

Email v.a.ferro@strath.ac.uk
Open Access Journal of Contraception 2013:4 I-II

(C) 2013 Garside et al, publisher and licensee Dove Medical Press Ltd. This is an Open Access article which permits unrestricted noncommercial use, provided the original work is properly cited.
Dovepress 


\section{Male contraceptive options}

Current options available to men include withdrawal (coitus interruptus), condoms - categorized as behavioral and barrier methods, respectively - and vasectomy. ${ }^{6}$ While the withdrawal method is considered unreliable, condom use has increased due to recognition of a need for protection against sexually transmitted infections and few adverse side effects. Current condom developments include the use of newer polyurethane materials, which are thinner, stronger, and less allergenic, and the inclusion of more effective spermicides. ${ }^{7}$ In contrast, vasectomy is considered a safe and simple method, but the drawback is that it is not reliably reversible and there is still a $<1 \%$ chance of unwanted pregnancy. ${ }^{8}$

In recent years, a growing number of new methods have emerged, such as reversible inhibition of sperm under guidance (RISUG), or "Vasalgel", as an alternative to vasectomy, most of which are still under development. RISUG is in Phase III clinical trials in India and is now also being investigated in the USA. RISUG involves the injection of a polymer into the vas deferens, rather than severing or clamping it, as in vasectomy. The polymer coats the inside walls of the vas deferens and solidifies and anchors itself to the microscopic folds of the inner walls of the vas deferens. As sperm come into contact with the polymer, the combination of positive and negative charges on the polymer damage the sperm, rendering them immotile. ${ }^{9}$ It is proposed that the polymer can be removed from the vas deferens, thereby restoring fertility.

Apart from mechanical methods, which have seen few emerging options, new technologies generally fall into two categories: hormonal and nonhormonal. The requirements for the ideal male contraceptive include that it:

- Be acceptable to both partners.

- Be effective (preferably without a lag period).

- Can be applied independently of the sexual act.

- Should not interfere with libido or sexual activity.

- Not have unacceptable side effects (long or short).

- Be fully reversible without impact on subsequent offspring.

- Have equivalent effectiveness to female methods.

A summary of emerging male contraceptive options is given in Table 1.

\section{Male hormonal contraceptives}

Male hormonal contraceptive methods are based on the suppression of luteinizing hormone ( $\mathrm{LH}$ ) and follicle-stimulating hormone (FSH) to decrease testosterone levels. In particular, intratesticular testosterone has to be drastically curtailed to effectively disrupt spermatogenesis. ${ }^{10}$ However, circulating testosterone has to be maintained at a particular level to retain androgenicity and this is usually achieved by addback therapy.

Testosterone-based therapies have been developed to suppress LH and FSH. Historically, these have included testosterone enanthate (200 mg administered by weekly intramuscular injection) ${ }^{11}$ and testosterone undecanoate (1000 mg administered every 4 weeks by depot injection this is now sold as Nebido ${ }^{\circledR}$ (Bayer Healthcare, Monheim, Germany) for treating hypogonadism). ${ }^{8}$ However, since testosterone-only therapies do not achieve azoospermia in all ethnicities (eg, lower response in Caucasians compared with total azoospermia achieved in East Asian men), other fertility disrupting agents are also required with longer lasting effects. ${ }^{12}$ Developments included testosterone plus depot medroxyprogesterone acetate (administered at 3-weekly intervals), ${ }^{13}$ testosterone plus 19-norethisterone enanthate (administered 8 -weekly by injection), ${ }^{14}$ and testosterone plus etonogestrel (injection and implant). ${ }^{15}$ However, the organizations/firms that initiated this research subsequently abandoned these male contraception programs and the work on them ceased. More recently, combinations of testosterone with gonadotropin-releasing hormone $(\mathrm{GnRH})$ analogs and newer progestogens such as nestorone have been examined. However, the costs of manufacture and need for daily or weekly administration of the GnRH preparations proved prohibitive for further research to be pursued. ${ }^{12}$ In contrast, daily use of testosterone/nestorone gel formulations has been shown to suppress sperm levels to $\leq 1$ million sperm $/ \mathrm{mL}$ in $89 \%$ of men, with few adverse effects. ${ }^{16}$ Nieschlag ${ }^{12}$ has comprehensively summarized the advantages and disadvantages of the various testosterone and testosterone combination formulations.

A potential androgen for the future, which may enable single-agent development, is dimethandrolone undeconoate (DMAU). This androgen binds to progesterone receptors and can be administered orally or by injection ${ }^{17}$ but has yet to be tested clinically.

\section{Immunocontraception of hormonal targets}

Contraceptive vaccines (immunocontraception) against various hormonal targets have been investigated over the last two decades. The most successful of these is currently used to control animal fertility and is based on the neutralization of GnRH (GonaCon ${ }^{\mathrm{TM}}$, United States Department of Agriculture, PA, USA). ${ }^{18-20}$ Figure 1 shows how immunoneutralization of GnRH affects synthesis of LH and FSH, which in turn affects testosterone production and spermatogenesis. A recent review examined other hormonal targets for male immunocontraception, including immunization against LH 
Table I Emerging contraceptive targets

\begin{tabular}{|c|c|c|c|c|c|}
\hline Contraceptive & Mechanism & Target & $\begin{array}{l}\text { Commercial } \\
\text { possibility }\end{array}$ & Reversible & Reference \\
\hline \multicolumn{6}{|l|}{ Barrier and vasectomy } \\
\hline Condom & Sperm barrier & Sperm containment & Yes & Yes & $\begin{array}{l}\text { Qureshi and } \\
\text { Attaran }\end{array}$ \\
\hline $\begin{array}{l}\text { Reversible inhibition of } \\
\text { sperm under guidance }\end{array}$ & Vasectomy & Sperm motility & Yes & Yes & $\begin{array}{l}\text { Chaudhury } \\
\text { et al }{ }^{9}\end{array}$ \\
\hline \multicolumn{6}{|l|}{ Hormonal } \\
\hline Testosterone & $\begin{array}{l}\text { Inhibiting gonadotropin } \\
\text { production }\end{array}$ & $\begin{array}{l}\text { Spermatogenesis } \\
\text { and testosterone }\end{array}$ & Possibly & $\begin{array}{l}\text { Yes, though may } \\
\text { depend on length } \\
\text { of time administered }\end{array}$ & $\begin{array}{l}\text { Nieschlag }{ }^{10} \\
\text { Nieschlag } \\
\text { et } \text { al }^{78}\end{array}$ \\
\hline $\begin{array}{l}\text { Testosterone } \\
\text { combinations }\end{array}$ & $\begin{array}{l}\text { Inhibiting gonadotropin } \\
\text { (LH, FSH) production }\end{array}$ & $\begin{array}{l}\text { Spermatogenesis } \\
\text { and testosterone }\end{array}$ & Possibly & $\begin{array}{l}\text { Depends on length } \\
\text { of time administered }\end{array}$ & Nieschlag ${ }^{10}$ \\
\hline Immunocontraceptives & $\begin{array}{l}\text { Inhibiting gonadotropin- } \\
\text { releasing hormone and } \\
\text { gonadotropins (LH, FSH) }\end{array}$ & $\begin{array}{l}\text { Spermatogenesis } \\
\text { and testosterone }\end{array}$ & Possibly & $\begin{array}{l}\text { Depends on } \\
\text { length of time } \\
\text { administered }\end{array}$ & $\begin{array}{l}\text { Ferro and } \\
\text { Garside }^{2 !}\end{array}$ \\
\hline \multicolumn{6}{|l|}{ Nonhormonal } \\
\hline Sperm protein vaccines & Inhibiting sperm function & $\begin{array}{l}\text { Sperm motility, } \\
\text { sperm-egg binding }\end{array}$ & $\begin{array}{l}\text { Yes: depends on } \\
\text { vaccine development }\end{array}$ & Yes & $\mathrm{Naz}^{32}$ \\
\hline Epididymal proteins & Inhibiting sperm function & $\begin{array}{l}\text { Sperm motility, } \\
\text { sperm-egg binding }\end{array}$ & $\begin{array}{l}\text { Possibly: EPPIN, } \\
\text { SEMGI }\end{array}$ & Unknown & $\begin{array}{l}\text { Silva et al }{ }^{41} \\
\text { Robert and } \\
\text { Gagnon }{ }^{42}\end{array}$ \\
\hline Testicular kinases & $\begin{array}{l}\text { Spermatogenesis and } \\
\text { fertilization }\end{array}$ & $\begin{array}{l}\text { Disrupt sperm } \\
\text { production and } \\
\text { fertilization }\end{array}$ & Unknown & Unknown & Xu et $\mathrm{a}^{47}$ \\
\hline Blood-testis boundary & Spermatogenesis & $\begin{array}{l}\text { Disrupt sperm } \\
\text { production }\end{array}$ & Unknown & Unknown & Mital et al ${ }^{34}$ \\
\hline Opioids & $\begin{array}{l}\text { Hormone production, } \\
\text { sperm function }\end{array}$ & $\begin{array}{l}\text { Act at several levels } \\
\text { of sperm production } \\
\text { and function }\end{array}$ & Unknown & Unknown & $\begin{array}{l}\text { Subiran } \\
\text { et }\left.\right|^{52}\end{array}$ \\
\hline Lonidamine derivatives & Spermatogenesis & $\begin{array}{l}\text { Prevent release of } \\
\text { sperm from Sertoli cells }\end{array}$ & Unknown & Unknown & $\begin{array}{l}\text { Cheng } \\
\text { et al }\end{array}$ \\
\hline Retinoic acid & Spermatogenesis & $\begin{array}{l}\text { Disrupt sperm } \\
\text { production }\end{array}$ & Unknown & Unknown & $\begin{array}{l}\text { Brooks and } \\
\text { van der } \\
\text { Horst }^{58}\end{array}$ \\
\hline miRNAs & Spermatogenesis & $\begin{array}{l}\text { Disrupt sperm } \\
\text { production }\end{array}$ & $\begin{array}{l}\text { Research stage } \\
\text { too early }\end{array}$ & Unknown & $\begin{array}{l}\text { Papaioannou } \\
\text { and Nef }{ }^{60}\end{array}$ \\
\hline Plant extracts & Spermatogenesis & $\begin{array}{l}\text { Disrupt sperm } \\
\text { production }\end{array}$ & $\begin{array}{l}\text { Unknown: most } \\
\text { have shown toxicity }\end{array}$ & Unknown & $\begin{array}{l}\text { Ogbuewu } \\
\text { et al }{ }^{66}\end{array}$ \\
\hline Heat treatment & Spermatogenesis & $\begin{array}{l}\text { Disrupt sperm } \\
\text { production }\end{array}$ & Possibly & $\begin{array}{l}\text { Yes: for short- } \\
\text { term application }\end{array}$ & Setchell ${ }^{69}$ \\
\hline
\end{tabular}

Abbreviations: miRNA, microribonucleic acid; LH, luteinizing hormone; FSH, follicle stimulating hormone; EPPIN, epididymal protease inhibitor; SEMGI, semenogelin I.

and FSH, but this work on these gonadotrophins is no longer being investigated clinically for contraception. ${ }^{21}$

\section{Risks and benefits associated with hormonal contraceptives}

Achieving acceptable levels of oligospermia or, if possible, azoospermia, requires intratesticular serum testosterone levels to drop to the hypogonadal range (typically below $350 \mathrm{ng} / \mathrm{dL})^{8}$ - this potentially increases the risk of loss of androgenicity, affecting the male sexual organs and characteristics, bone structure, and libido, as well as resulting in negative psychotropic effects. ${ }^{10}$ This can be improved by targeting intratesticular testosterone using a dual-action con- traceptive - that is, combining the addition of testosterone with substances that suppress the secretion of LH or FSH (or both), while replacing systemic testosterone by combining the contraceptive with an androgen. It is believed that by doing so the vast majority of hormonal contraceptives can maintain a high level of efficacy with minimal side effects, although most have not focused on the side effects. ${ }^{22}$ The most common of which include acne, suppression of high-density lipoprotein cholesterol, and a slight increase in hematocrit (due to suppression of hepcidin), all of which can be satisfactorily monitored. ${ }^{23}$ Other side effects - such as night sweats and decrease in testis volume - are reversible and, although commonly experienced, raise little concern and 


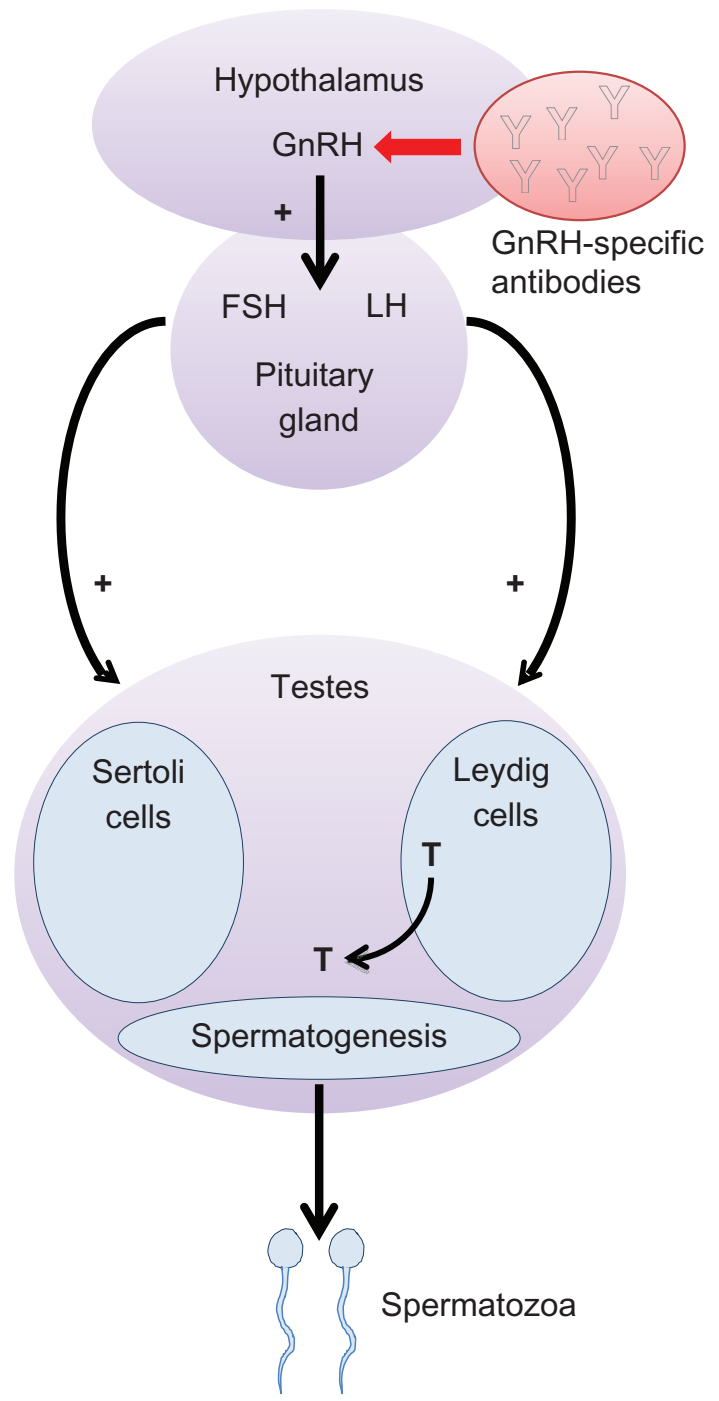

Figure I Control of male fertility by immunization against gonadotropin-releasing hormone $(\mathrm{GnRH})$.

Notes: Vaccination against GnRH produces antibodies that act by neutralizing $\mathrm{GnRH}$ in the hypothalamus, which in turn affects secretion of follicle-stimulating hormone (FSH), luteinizing hormone ( $\mathrm{LH})$, and testosterone $(\mathrm{T})$ and, ultimately, spermatogenesis.

are unlikely to result in discontinuation of the treatment. ${ }^{24}$ However, as with a large number of hormonal treatments, there is a risk of psychotropic effects, including irritability, anxiety, depression, and an increase in emotionally fragile states - these psychotropic effects can be severe enough to result in the subject withdrawing from the treatment program..$^{25}$

Of course, the side effects vary depending on the contraceptive used and the administration route. Apart from the increase in testosterone levels causing acne, general skin irritation and tenderness is frequently found at the site of injection, patch application, or transdermal preparations. ${ }^{25}$ For hypogonadal men, there is a further risk of gynecomastia (development of larger than normal mammary glands in males).

It should be noted that targeting LH and FSH decreases sperm production but does not affect sperm that have already been produced; therefore, other contraceptive methods must be used until existing sperm have reached maturity and exited the testicles - this typically takes $2-3$ months. ${ }^{26}$ There is also a delay in return to the male's natural sperm count after discontinuing the treatment ${ }^{26}$ - in the case of testosterone plus depot medroxyprogesterone acetate, this delay can last several months. ${ }^{10}$ Overall, however, the high efficacy of hormonal contraceptives outweigh the small concerns of side effects. It should also be noted that early concerns about an increase in cardiovascular disease or prostate cancer risk have so far been unfounded. ${ }^{25}$

\section{Male nonhormonal contraceptives}

Research into nonhormonal methods of male contraception are numerous and the focus of this section is on novel technologies that are at various stages of development and/ or in clinical trial, thus may be the male contraceptives of the future. Three significant areas of development include (1) the immunization (active or passive) of males with antigens/antibodies that can block sperm function; (2) the administration of site-directed compounds to block spermatogenesis or specific sperm function(s) necessary for normal fertilization; and (3) the administration of herbal extracts or compounds to suppress sperm production and/or function. These approaches, which are noninvasive and aim to be reversible, are discussed in the following sections.

\section{Immunocontraception: sperm proteins}

Immunocontraception against various nonhormonal reproductive targets has been investigated over the last decade. These targets include the successful zona pellucida targets used for animal castration in females (SpayVac ${ }^{\mathrm{TM}}$, SpayVac ${ }^{\mathrm{TM}}$ for Wildlife Inc, Princeton, NJ, USA). ${ }^{27,28}$ Sperm proteins are an attractive target as they are highly immunogenic, having both auto- and isoantigens, are often specific to sperm, and thus do not affect other biological processes. Sperm proteins that have been investigated to date have been chosen especially for their sperm specificity, surface expression, involvement in fertility, and ability to raise high antibody titers that can neutralize fertility components. Antigens that are involved in human immune infertility are particularly attractive candidates. One of the first sperm proteins shown to induce specific serum immunoglobulin (Ig) G antibodies and IgA antibodies in vaginal fluids after administration to female 
Table 2 Sperm proteins under investigation for contraceptive potential in males and females

\begin{tabular}{|c|c|c|}
\hline Sperm protein & Investigator/s & Year \\
\hline $\mathrm{PH}-20$ & Primakoff et al ${ }^{79}$ & 1988 \\
\hline SPIO & Herr et $\mathrm{a}^{80}$ & 1990 \\
\hline ZRK & Alexander ${ }^{81}$ & 1995 \\
\hline $\mathrm{PH} 30$ & Vidaeus et $\mathrm{al}^{82}$ & 1997 \\
\hline SPI7 & Lea et $\mathrm{al}^{83}$ & 1998 \\
\hline CD52 & Diekman et al ${ }^{84}$ & 2000 \\
\hline Acrosin & Howes and Jones ${ }^{85}$ & 2002 \\
\hline SPAG9 & Jagadish et $\mathrm{a}^{86}$ & 2006 \\
\hline SAGA-I & Xu et $\mathrm{al}^{87}$ & 2007 \\
\hline Izumo & Wang et $\mathrm{a}^{88}$ & 2009 \\
\hline ESP & Lv et $\mathrm{al}^{89}$ & 2010 \\
\hline CatSper & Hildebrand et $\mathrm{al}^{90}$ & 2010 \\
\hline Proacrosin & García et al ${ }^{39}$ & 2012 \\
\hline $\mathrm{LDH}-\mathrm{C} 4$ & Gupta91 & 2012 \\
\hline
\end{tabular}

mice was SP10. ${ }^{29}$ Some of the most researched sperm proteins are given in Table 2. As several reviews have provided detailed overviews of the research and status of anti-sperm contraceptive vaccines and details of many of the sperm proteins investigated, ${ }^{30-32}$ these will not be addressed here.

The list of sperm proteins being investigated for immunocontraception continues to grow and gene knockout technology has provided an invaluable tool for identifying numerous sperm peptides that may have a role in sperm function. However, many of these have only been investigated in the female for their ability to prevent sperm function within the female reproductive tract (eg, sperm-egg binding, capacitation). Few have been investigated for their ability to inhibit sperm function, such as motility, when administered to the male. This is primarily due to the incomplete understanding of male reproductive tract immunobiology and also to the large numbers of sperm that are required to be neutralized in the male epididymis and testis. The female reproductive tract poses fewer challenges to the successful inhibition of sperm function by an anti-sperm immunocontraceptive, due to the lower numbers of sperm presented in each ejaculate. Recent research has helped to move forward our understanding the immunological roles of both the testis and epididymis and the blood-testis barrier. ${ }^{33,34}$ This can only help facilitate the development of contraceptive vaccines for the male.

It also seems that the use of a single antigen in the development of an anti-sperm vaccine may not provide a sufficient antibody response to reliably and consistently block fertility. Researchers are now looking at developing vaccines with more than one sperm protein in a single vaccine design. ${ }^{35}$
In addition, new developments in vaccine technology, such as improved adjuvants ${ }^{36,37}$ and DNA vaccines, ${ }^{38}$ offer the potential to develop more effective and reliable contraceptive vaccines. Such vaccines have already shown efficacy when administered to male mice, ${ }^{39}$ thus may provide a way forward for reliable male immunocontraception.

\section{Epididymal proteins}

The epididymis is the site where sperm maturation occurs and is therefore a reasonable target for a male antifertility product. Spermatozoa become motile and are able to recognize and fertilize an egg once they have progressed through the epididymis. As such, it is desirable to identify targets that interfere with this process and therefore be likely to inhibit sperm function. However, to date, attempts to interfere with either sperm maturation or epididymal function have not been successful. ${ }^{40}$ Some potential epididymal targets have been identified using transgenic animals but none has provided effective inhibition of sperm function.

The most promising target is proving to be the epididymal protease inhibitor (EPPIN), a cysteine-rich protein that has antimicrobial properties and is thought to play a critical role in sperm motility. Eppin messenger RNA (mRNA) and the protein itself are found in abundance in both testis and epididymis of rats. Reverse-transcriptase polymerase chain reaction studies have demonstrated that the mRNA is also found in Sertoli and spermatogenic cells. Surgical castration downregulates EPPIN (mRNA and protein) expression levels in the caput and cauda epididymis, an effect that is reversed by testosterone replacement. ${ }^{41}$

During ejaculation, semenogelin (SEMG1) from seminal vesicles binds to EPPIN, initiating a series of events that includes the modulation of prostate-specific antigen (PSA) enzyme activity, provision of antimicrobial protection, causing inhibition of sperm motility. ${ }^{42}$ As PSA hydrolyses SEMG1, spermatozoa gain progressive motility. The immunization of male monkeys with recombinant EPPIN resulted in total, but reversible, contraception, demonstrating that it has a key role in male fertility. ${ }^{43}$ Currently, compounds that inhibit EPPIN function are being developed to provide additional information on its activities and whether it will become a suitable target for a prospective male contraceptive. ${ }^{44}$

In relation to the EPPIN studies, research has shown that the treatment of live spermatozoa with SEMG1 decreases the straight-line velocity and linearity of human spermatozoa. ${ }^{45}$ This occurs in a dose- and time-dependent manner and subsequent treatment with PSA reverses the inhibition of progressive motility. Cysteine 239 of SEMG1 appears to be 
critical for binding to EPPIN and inhibiting sperm motility. ${ }^{46}$ SEMG1 may also have potential as a candidate target for male contraception.

\section{Testicular kinases}

Recently, there has been interest in testis-specific serine/ threonine kinases (TSSKs) as contraceptive targets and, as a result, focus on the development of small-molecule kinase inhibitors, which may inhibit fertility. These kinases and the substrates TSSK1-4, small serine/threonine kinase (SSTK), and testis-specific serine kinase substrate (TSKS) are part of a family that is abundant in the testis and may provide tissuespecific targets for contraceptive development. ${ }^{47}$ In rodents, in situ hybridization has confirmed that TSSK2, SSTK, and TSKS are post-meiotic in their expression patterns. This makes them possible targets for reversible contraceptive intervention by preserving spermatogonia and spermatocytes. The current research may indicate that high-throughput screening of inhibitors for TSKS phosphorylation could provide targets for male contraception. However, this family of kinases is not strictly testis specific and may, therefore, not be suitable for human contraception.

Another group of kinases that has a role in spermatogenesis is the tyrosine kinases, specifically the Src family and its subfamilies - for example, the Fes-related protein (Fer) subfamily. FerT (the truncated form) regulates actin assembly and disassembly, mediated by phosphorylation of cortactin. It is present in the "acroplaxome," a cytoskeletal plate containing an F-actin network that links the acrosome to the spermatid nuclear envelope. This finding indicates that Fer kinase may represent one of the tyrosine protein kinases that contributes to spermatid headshaping. ${ }^{48}$

The specific roles of kinases in spermatogenesis and fertilization are a relatively new area of research and more information is required before it will be possible to evaluate if kinases will play a role in male contraceptive development.

\section{Blood-testis boundary: epigenetic reader proteins (ERPs)}

A new and interesting approach to male contraception has come from advances in the understanding of spermatogenesis at the molecular level. ERPs are involved in the chromatin remodelling of spermatogenesis, particularly bromodomain testis-specific protein (BRDT), a member of the bromodomain and extraterminal family of ERPs. "BRDT" is a tissue-restricted chromatin-associated protein located in pachytene and diplotene spermatocytes and spermatids. ${ }^{49}$ It has recently been associated with both azoospermia and oligospermia in men. ${ }^{50}$ Interestingly, it has also been shown that suppression of BRDT function by a small-molecule, bromodomain inhibitor exerts a dose- and time-dependent inhibition on spermatogenesis in mice. ${ }^{51}$ Both human and mouse BRDT are highly conserved and seem to have nearly identical bromodomain pockets, indicating that the findings might be able to be translated to human males; this would potentially provide a novel and exciting approach for a smallmolecule-based male contraceptive.

\section{Opioids}

Opioids, which comprise part of the neuroendocrine system, are involved in the control of the male reproductive system on several levels. They are involved in the release of gonadotropins from the pituitary (Figure 2A); the function of Sertoli cells in the testis (Figure 2B); and the function and motility of spermatozoa (Figure 2C and D). ${ }^{52}$ The opioid system is controlled by endogenous opioid peptides (EOPs), which exert their action through opioid receptors for which the EOPs exhibit different affinities. Within the testis, the EOPs

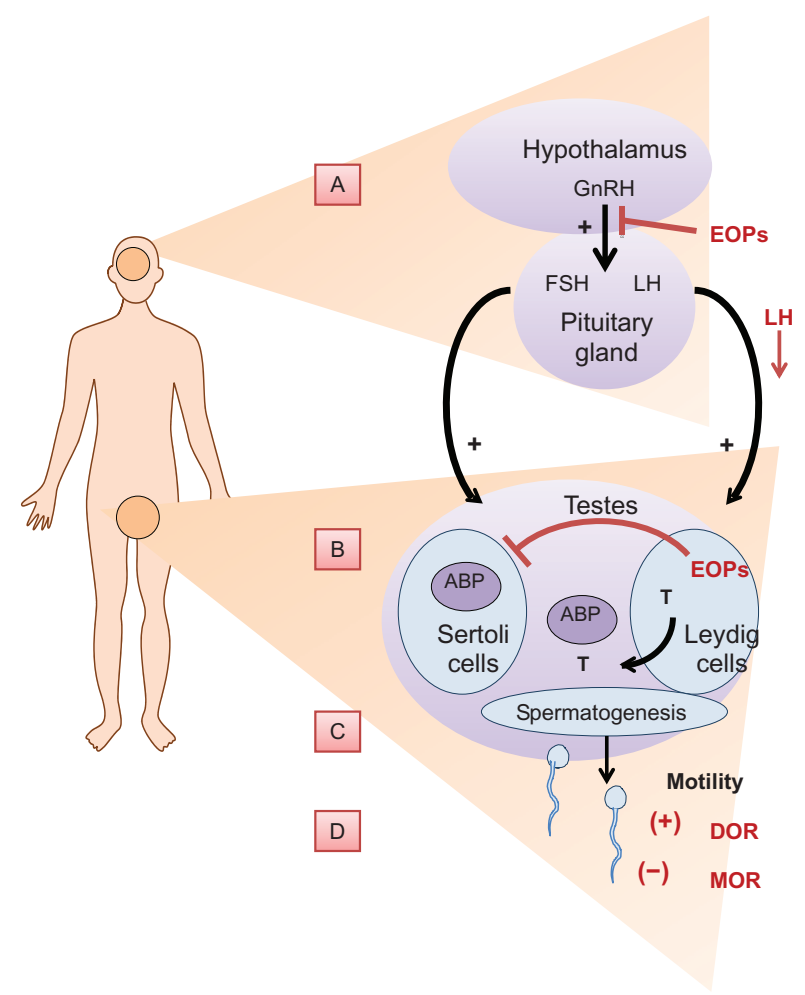

Figure 2 Control of male fertility using the opioid system. (A) Control of gonadotropin-releasing hormone $(\mathrm{GnRH})$ secretion, which in turn suppresses luteinizing hormone (LH) release; (B) control of opioid synthesis by LH in Leydig cells, which inhibits Sertoli cell function and testosterone levels that inhibit production of androgen-binding protein (ABP), which is stimulated by folliclestimulating hormone (FSH) in Sertoli cells; (C) genetic control of opioid precursors that control spermatogenesis; and (D) further control of spermatozoa motility via receptors (mu-opioid receptor [MOR] and delta-opioid receptor [DOR]).

Abbreviations: EOPs, endogenous opioid peptides; $T$, testosterone. 
are present in different cell types and appear to intervene in the control of spermatogenesis. Opioid precursors are expressed differentially in testicular somatic and germ cells, suggesting that EOPs regulate testicular function locally by de novo synthesis. For example, LH stimulates production of EOPs in Leydig cells, and these suppress the role of Sertoli cells in a paracrine manner. However, the role of EOPs in germ-line sperm cells is still unknown. In addition, opioid receptors have been located on human sperm, which may indicate that EOPs directly affect sperm function, particularly sperm motility. ${ }^{53}$ With further research, EOPs may open up an area of novel contraceptive research and contribute to the development of novel nonhormonal male contraceptives.

\section{Lonidamine derivatives: adjudin and gamendazole}

Adjudin disrupts adhesion of spermatids to Sertoli cells and, in animals (male rats), weekly doses can induce total infertility 5 weeks after treatment. ${ }^{54}$ Similarly, another derivative, H2-gamendazole, has been shown to induce $100 \%$ infertility after just one dose in male rats, and it is possible that this compound will progress to clinical trial. ${ }^{55}$ However, it will need to show that it does not have long-term effects on the testis and that its contraceptive effect is reversible.

\section{Retinoic acid (RA)}

It is well established that the sperm production process, "spermatogenesis," relies on the presence of vitamin A. ${ }^{56}$ RA, the active metabolite of vitamin A, is required for spermatogonial differentiation and the production of sufficient numbers of sperm for fertilization. ${ }^{57}$ RA binds RA receptors that control gene expression. ${ }^{55}$ Certain compounds, such as bisdichloroacetyldiamines (eg, WIN 18446) have been shown to reversibly inhibit spermatogenesis by inhibiting testicular RA synthesis. ${ }^{58}$ However, to be a viable contraceptive, they also must not interfere with retinoic function or synthesis in non-testicular tissue. Currently, research is continuing on the development of novel inhibitors of retinoic synthesis that only affect spermatogenesis, but none are currently available.

Further, an RA receptor antagonist, BMS-189453, is also showing promise based on results in male rodents. ${ }^{59}$

\section{MicroRNAs (miRNAs) and spermatogenesis}

A new and exciting area of male reproductive research is the role of miRNAs in male fertility. The process of spermatogenesis is strictly regulated to enable and maintain the continuous production of spermatozoa. A novel mechanism of the post-transcriptional control of spermatogenesis, mediated by miRNAs, has recently been shown to be an important regulator of this process. ${ }^{60}$ miRNAs are endogenous, small, non-coding fragments produced through a multistep enzymatic process, which involves the action of Dicer (Dcr), an RNase III endonuclease. ${ }^{61}$ Dcr plays a key role in the biogenesis of miRNAs. To study RNA interference mechanisms in mammals, the first Dcr knockout mouse was generated by Bernstein et al. ${ }^{62}$ In their work, loss of Dcr led to early embryonic lethality and was characterized by almost total absence of embryonic stem cells, showing that Dcr is essential for murine embryonic development. ${ }^{62}$

Following on from these studies, the role of miRNAs in spermatogenesis ${ }^{63,64}$ and in Sertoli cell function ${ }^{65}$ was investigated. It was found that spermatogenesis was disrupted if miRNAs were absent and the selective ablation of Dcr in Sertoli cells resulted in infertility, due to complete absence of spermatozoa. These experiments have opened up an intriguing aspect of testicular function and paracrine control. Although much more research needs to be undertaken on the role of miRNAs in spermatogenesis, such future work will increase our understanding of male fertility and possibly lead to new areas of male contraceptive research.

\section{Plant extracts}

Plants have been used for millennia for medicinal purposes, including in prevention of pregnancy and as abortifacient agents. Indeed, the first female oral contraceptive was derived from the roots of the Mexican wild yam. ${ }^{21} \mathrm{~A}$ recent review has examined the effects of different plant extracts on steroidogenesis and spermatogenesis. ${ }^{66}$ The most widely researched plants to demonstrate nonhormonal antifertility effects are neem (Azadirachta indica) and gossypol, an extract of cottonseed oil. The latter has been studied in more than 8000 men and found to be very effective in producing azoospermia. However, it is very toxic and causes hypokalemia and irreversible infertility as a result of damage to the seminiferous epithelium. ${ }^{67,68}$ While many plant compounds have been researched, the quality control, safety, and mechanisms of action of plants have been less well studied. If this hurdle can be overcome, plants could offer a cost-effective source for male contraceptives, which could have relevance in lowincome countries.

\section{Heat treatment}

One method that does not fit into the chemical nonhormonal category is heat treatment. The use of local testicular heat treatment can cause reversible oligospermia or azoospermia via germ cell apoptosis. ${ }^{69}$ This method has recently been investigated as a possible male contraceptive. Liu ${ }^{70}$ showed 
that single exposure of rat or monkey testes to a temperature of $43^{\circ} \mathrm{C}$ resulted in specific and reversible damage to the seminiferous epithelium. Local warming (30 minutes/day for 2 days) of monkey testes at $43^{\circ} \mathrm{C}$ showed that the sperm counts in the semen decreased by up to $80 \%$ at 28 days; further, this effect was reversible. In addition, when heat treatment was given in combination with a testosterone implant, the sperm count dropped to zero within 2 months. Withdrawal of the testosterone caused the count to recover to normal levels after 2-3 months. As such, this research has provided a theoretical, though perhaps impractical, basis for designing a combined male contraceptive.

\section{Acceptability}

For the past 50 years, researchers and family planning organizations have focused on female methods of contraception in the belief that women bear most of the health and economic impact of childbearing and child raising. However, since the mid-1990s, there has been a change in attitude and it is now recognized that contraceptives should be developed for both men and women.

The acceptability of male contraception can be measured by the prevalence and continuation of use of a particular method. Men are mostly involved in decisions of pregnancy prevention methods when part of a married or in-union couple and male contraceptive methods account for about $26 \%$ of the global contraceptive prevalence. ${ }^{71}$ Historically, the male methods of withdrawal and periodic abstinence have been the only contraceptive methods used and accepted by men ${ }^{72}$ and although these methods are still currently in use by almost 35 million couples around the world, it appears that prevalence is dependent on cultural, religious, economic, and relationship status. These methods comprise only $6.6 \%$ of the contraceptives used in the world today. ${ }^{73}$

Condoms and vasectomy are so-called modern methods of contraception that are accessible to men. While use of condoms has increased, vasectomy has decreased in some countries due to the advent of female sterilization. ${ }^{74}$ Differences can be seen between regions of the world, with $17.8 \%$ of male condom use occurring in more developed regions compared with $6.9 \%$ in less developed regions. ${ }^{73}$ There are also variations in prevalence of male condom use within regions. For example, considering more developed regions, male condom use in Hong Kong and Japan, accounts for 50\% and $40 \%$, respectively, of all the contraceptive measures used in these countries, while it accounts for only $1.1 \%$ in Germany.
Similarly, the percentage of use in less developed regions varies from $15.5 \%$ in Botswana to $0.2 \%$ in Samoa. ${ }^{73}$

Worldwide, vasectomy accounts for about $2.4 \%$ of all used male contraception methods. It is most preferred in more developed countries and educated communities; for example, more than $20 \%$ of men in Canada and the UK choose it for preventing pregnancy. However, again, prevalence varies across regions; in Germany, for example, this method accounts for only $0.5 \%$ of all contraceptive methods used. Prevalence is much lower in less developed countries, with almost no men in African countries, for example, opting for surgical sterility.

All reported acceptability data have been based on trial surveys carried out among young men and their partners. A male pill or injection has been reported to be considered very acceptable by both men and women, as it may increase choice of reversible sterility methods. ${ }^{6}$ Further, more than threequarters of men who participated in hormonal contraception clinical trials from six different cultural settings reported their intention to definitely or probably use such methods in the future when available. ${ }^{75}$ In another study, men and women were interviewed in Edinburgh, Shanghai, Hong Kong, and Cape Town and between $44 \%$ and $88 \%$ of men stated that they would use a daily contraceptive pill. In contrast, most women $(70 \%$ [from Hong Kong] to $>90 \%$ [Cape Town and Edinburgh]) thought it was a good idea and only $2 \%$ said that they would not trust their partners to take the male pill. ${ }^{75} \mathrm{~A}$ wider survey in nine countries over four continents consisting of 9000 men aged 18 to 50 years indicated that $>55 \%$ would accept use of a male contraceptive method and that the most preferred method was a daily oral pill, the second most preferred method was monthly injection, then yearly implant. ${ }^{76}$ Studies have also shown that although men have an increasing knowledge of the male contraceptive choices available to them, they may not use these methods. ${ }^{77}$ Education, cultural and religious beliefs remain hurdles to acceptability.

\section{Future prospects}

From the overview of methods in development provided, the most promising new method appears to be RISUG as an alternative to vasectomy. However, this method may not be widely accepted (given the current prevalence of vasectomy for contraceptive purposes) and require specialist application. In the short-term, the likeliest method to be made readily available and be widely accepted would be a hormonal contraceptive pill. However, without commitment to a daily regime, this method would prove ineffective if compliance were compromised. Long-term, research into 
suitable targets for immunocontraception may well provide a source for new-generation male contraceptive products such as those administered via mucosal vaccination. Vaccination removes the need for a daily regime, while the mucosal route potentially allows for self-administration.

\section{Conclusion}

In the near future, the choice of male contraceptive methods may increase. However, the availability of more male contraceptive methods is insufficient by itself. There is also an urgent requirement for governments and nongovernment organizations to break the gender imbalance concerning contraceptive usage that exists globally, and which continues to be an obstacle to effective population control. The introduction of hormonal contraception for women was seen as revolutionary in that it empowered women and provided them with the opportunity to control their fertility. However, the success of female hormonal contraception, particularly in the developed world, has in many ways been detrimental and has perpetuated the view that contraceptive responsibility and its associated health and financial burdens remain with women. Although this has been considered to provide women empowerment and equality, which may no doubt be true, it has until recently stifled innovation in male contraception, with the focus of continued contraceptive development and adoption placed on females. Perhaps it is time for males to accept that male reproductive autonomy could also be empowering for them as it has been for women and is a valid price to pay for sexual liberalization. More widely, it also provides males with the opportunity to jointly accept and contribute to population control.

With regard to the commercial production of novel male contraceptives, the current consolidation of pharmaceutical companies has reduced competition and this has been compounded by the loss of profitability of many contraceptives due to short-lasting patents. Health care reforms - such as those in the USA - may also further discourage new product development. However, the creation of new contraceptives may still be possible through the efforts of small start-up companies, philanthropic foundations, and governmental research enterprises.

Progress is being made in terms of new hormonal and nonhormonal drug targets, as evidenced by the increase in published studies, even in the last year. While the global economy is in recession, there is an even greater need for increasing the availability of cost-effective and safe contraceptive options.

\section{Disclosure}

The authors report no conflicts of interest in this work.

\section{References}

1. Trussell J, Henry N, Hassan F, Prezioso A, Law A, Filonenko A. Burden of unintended pregnancy in the United States: potential savings with increased use of long-acting reversible contraception. Contraception. 2013;87(2);154-161.

2. Kopf GS. Contraceptive development: targets, approaches and challenges. Soc Reprod Fertil Suppl. 2007;63:421-431.

3. Grimes DA, Lopez LM, Gallo MF, Halpern V, Nanda K, Schulz KF. Steroid hormones for contraception in men. Cochrane Database Syst Rev. 2012;3:CD004316.

4. Population Division of the United Nations Department of Economic and Social Affairs. World Population Prospects, the 2010 Revision. New York, NY: United Nations; 2011.

5. Cleland J, Conde-Agudelo A, Peterson H, Ross J, Tsui A. Contraception and health. Lancet. 2012;380(9837):149-156.

6. Glasier A. Acceptability of contraception for men: a review. Contraception. 2010;82(5):453-456.

7. Qureshi M, Attaran M. Review of newer contraceptive agents. Cleve Clin J Med. 1999;66(6):358-366.

8. Nieschlag E, Swerdloff R, Behre HM, et al. Investigation, treatment, and monitoring of late-onset hypogonadism in males: ISA, ISSAM, and EAU recommendations. J Androl. 2006;27(2):135-137.

9. Chaudhury K, Bhattacharyya AK, Guha SK. Studies on the membrane integrity of human sperm treated with a new injectable male contraceptive. Hum Reprod. 2004;19(8):1826-1830.

10. Nieschlag E. The struggle for male hormonal contraception. Best Pract Res Clin Endocrinol Metab. 2011;25(2):369-375.

11. [No authors listed]. Contraceptive efficacy of testosterone-induced azoospermia in normal men. World Health Organization Task Force on methods for the regulation of male fertility. Lancet. 1990; 336(8721):955-959.

12. Nieschlag E. Clinical trials in male hormonal contraception. Contraception. 2010;82(5):457-470.

13. [No authors listed]. Comparison of two androgens plus depot-medroxyprogesterone acetate for suppression to azoospermia in indonesian men. World Health Organization. Task Force on Methods for the Regulation of Male Fertility. Fert Steril. 1993;60(6):1062-1068.

14. Meriggiola MC, Costantino A, Saad F, et al. Norethisterone enanthate plus testosterone undecanoate for male contraception: effects of various injection intervals on spermatogenesis, reproductive hormones, testis, and prostate. J Clin Endocrinol Metab. 2005;90(4): 2005-2014.

15. Mommers E, Kersemaekers WM, Elliesen J, et al. Male hormonal contraception: a double-blind, placebo-controlled study. J Clin Endocrinol Metab. 2008;93(7):2572-2580.

16. Ilani N, Roth MY, Amory JK, et al. A new combination of testosterone and nestorone transdermal gels for male hormonal contraception. J Clin Endocrinol Metab. 2012;97(10):3476-3486.

17. Attardi BJ, Hild SA, Reel JR. Dimethandrolone undecanoate: a new potent orally active androgen with progestational activity. Endocrinology. 2006;147(6):3016-3026.

18. Massei G, Cowan DP, Coats J, et al. Long-term effects of immunocontraception on wild boar fertility, physiology and behaviour. Wildlife Research. 2012;39(5):378-385.

19. Levy JK, Friary JA, Miller LA, Tucker SJ, Fagerstone KA. Long-term fertility control in female cats with GonaCon ${ }^{\mathrm{TM}}$, a $\mathrm{GnRH}$ immunocontraceptive. Theriogenology. 2011;76(8):1517-1525.

20. Pai M, Bruner R, Schlafer DH, Yarrow GK, Yoder CA, Miller LA. Immunocontraception in Eastern gray squirrels (Sciurus carolinensis): morphologic changes in reproductive organs. J Zoo Wildl Med. 2011; 42(4):718-722. 
21. Ferro VA, Garside DA. Reproductive component vaccine developments for contraceptive and non-contraceptive uses. Expert Opin Ther Pat. 2011;21(9):1473-1482.

22. Nieschlag, N. Hormonal male contraception: end of a dream or start of a new era? Endocrine. 2012 Nov 18. [Epub ahead of print].

23. Roth MY, Amory JK. Pharmacologic development of male hormonal contraceptive agents. Clin Pharmacol Ther. 2011;89(1):133-136.

24. Hay CJ, Brady BM, Zitzmann M, et al. A multicenter phase IIb study of a novel combination of intramuscular androgen (testosterone decanoate) and oral progestogen (etonogestrel) for male hormonal contraception. J Clin Endocrinol Metab. 2005;90(4): 2042-2049.

25. Ilani N, Swerdloff RS, Wang C. Male hormonal contraception: potential risks and benefits. Rev Endocr Metab Dis. 2011;12(2): $107-117$.

26. Amory JK, Page ST, Bremner WJ. Drug insight: Recent advances in male hormonal contraception. Nat Clin Pract Endocrinol Metab. 2006;2(1):32-41.

27. Killian G, Thain D, Diehl NK, Rhyan J, Miller L. Four-year contraception rates of mares treated with single-injection porcine zona pellucida and $\mathrm{GnRH}$ vaccines and intrauterine devices. Wildlife Research. 2008;35(6):531-539.

28. Gray ME, Thain DS, Cameron EZ, Miller LA. Multi-year fertility reduction in free-roaming feral horses with single-injection immunocontraceptive formulations. Wildlife Res. 2010;37(6):475-481.

29. Srinivasan J, Tinge S, Wright R, Herr JC, Curtiss R 3rd. Oral immunization with attenuated Salmonella expressing human sperm antigen induces antibodies in serum and the reproductive tract. Biol Reprod. 1995;53(2):462-471.

30. Suri A. Sperm specific proteins-potential candidate molecules for fertility control. Reprod Biol Endocrinol. 2004;2:10.

31. Suri A. Sperm-based contraceptive vaccines: current status, merits and development. Expert Rev Mol Med. 2005;7(18):1-16.

32. Naz RK. Antisperm contraceptive vaccines: where we are and where we are going? Am J Reprod Immunol. 2011;66(1):5-12.

33. Hedger MP. Immunophysiology and pathology of inflammation in the testis and epididymis. J Androl. 2011;32(6):625-640.

34. Mital P, Hinton BT, Dufour JM. The blood-testis and blood-epididymis barriers are more than just their tight junctions. Biol Reprod. 2011;84(5): $851-858$.

35. Naz RK, Gupta SK, Gupta JC, Vyas HK, Talwar AG. Recent advances in contraceptive vaccine development: a mini-review. Hum Reprod. 2005;20(12):3271-3283.

36. Bode C, Zhao G, Steinhagen F, Kinjo T, Klinman DM. CpG DNA as a vaccine adjuvant. Expert Rev Vaccines. 2011;10(4):499-511.

37. Ma X, Li J, Zhang F. Intranasal co-delivery with the mouse zona pellucida 3 and GM-CSF expressing constructs enhances humoral immune responses and contraception in mice. Scand J Immunol. 2012;76(6): 521-527.

38. Chen Y, Zhang D, Xin N, et al. Construction of sperm-specific lactate dehydrogenase DNA vaccine and experimental study of its immunocontraceptive effect on mice. Sci China C Life Sci. 2008;51(4): 308-316.

39. García L, Veiga MF, Lustig L, Vazquez-Levin MH, Veaute C. DNA immunization against proacrosin impairs fertility in male mice. $\mathrm{Am} \mathrm{J}$ Reprod Immunol. 2012;68(1):56-67.

40. Hinton BT, Cooper TG. The epididymis as a target for male contraceptive development. Handb Exp Pharmacol. 2010;198:117-137.

41. Silva EJ, Hamil KG, Richardson RT, O'Rand MG. Characterization of EPPIN's semenogelin I binding site: a contraceptive drug target. Biol Reprod. 2012;87(3):56.

42. Robert M, Gagnon C. Sperm motility inhibitor from human seminal plasma: association with semen coagulum. Hum Reprod. 1995;10(8): 2192-2197.

43. O'Rand MG, Widgren EE, Hamil KG, Silva EJ, Richardson RT. Functional studies of eppin. Biochem Soc Trans. 2011;39(5):1447-1449.
44. Silva EJ, Patrão MT, Tsuruta JK, O’Rand MG, Avellar MC. Epididymal protease inhibitor (EPPIN) is differentially expressed in the male rat reproductive tract and immunolocalized in maturing spermatozoa. $\mathrm{Mol}$ Reprod Dev. 2012;79(12):832-842.

45. Yoshida K, Kawano N, Yoshiike M, Yoshida M, Iwamoto T, Morisawa M. Physiological roles of semenogelin I and zinc in sperm motility and semen coagulation on ejaculation in humans. Mol Hum Reprod. 2008;14(3):151-156.

46. Mitra A, Richardson RT, O'Rand MG. Analysis of recombinant human semenogelin as an inhibitor of human sperm motility. Biol Reprod. 2010;82(3):489-496.

47. Xu B, Hao Z, Jha KN, et al. Validation of a testis specific serine/ threonine kinase [TSSK] family and the substrate of TSSK1 and 2, TSKS, as contraceptive targets. Soc Reprod Fertil Suppl. 2007;63: $87-101$.

48. Kierszenbaum AL. Tyrosine protein kinases and spermatogenesis: truncation matters. Mol Reprod Dev. 2006;73(4):399-403.

49. Shang E, Nickerson HD, Wen D, Wang X, Wolgemuth DJ. The first bromodomain of Brdt, a testis-specific member of the BET sub-family of double-bromodomain-containing proteins, is essential for male germ cell differentiation. Development. 2007;134(19):3507-3515.

50. Aston KI, Krausz C, Laface I, Ruiz-Castané E, Carrell DT. Evaluation of 172 candidate polymorphisms for association with oligozoospermia or azoospermia in a large cohort of men of European descent. Hum Reprod. 2010;25(6):1383-1397.

51. Matzuk MM, McKeown MR, Filippakopoulos P, et al. Small-molecule inhibition of BRDT for male contraception. Cell. 2012;150(4): 673-684.

52. Subirán N, Casis L, Irazusta J. Regulation of male fertility by the opioid system. Mol Med. 2011;17(7-8):846-853.

53. Albrizio M, Lacalandra GM, Micera E, Guaricci AC, Nicassio M, Zarrilli A. Delta opioid receptor on equine sperm cells: subcellular localization and involvement in sperm motility analyzed by computer assisted sperm analyzer (CASA). Reprod Biol Endocrin. 2010;8:78.

54. Cheng CY, Silvestrini B, Grima J, et al. Two new male contraceptives exert their effects by depleting germ cells prematurely from the testis. Biol Reprod. 2001;65(2):449-461.

55. Nya-Ngatchou JJ, Amory JK. New approaches to male non-hormonal contraception. Contraception. 2013;87(3):296-299.

56. Hogarth CA, Griswold MD. The key role of vitamin A in spermatogenesis. J Clin Invest. 2010;120(4):956-962.

57. Hogarth CA, Amory JK, Griswold MD. Inhibiting vitamin A metabolism as an approach to male contraception. Trends Endocrinol Metab. 2011;22(4):136-144.

58. Brooks NL, van der Horst G. Short-term effects of $N^{\prime} N-$ bis(dichloroacetyl)-1,8-octamethylenediamine (WIN 18446) on the testes, selected sperm parameters and fertility of male CBA mice. Lab Anim. 2003;37(4):363-373.

59. Chung SSW, Wang XY, Roberts SS, Griffey SM, Reczek PR, Wolgemuth DJ. Oral administration of a retinoic acid receptor antagonist reversibly inhibits spermatogenesis in mice. Endocrinology. 2011;152(6):2492-2502.

60. Papaioannou MD, Nef S. microRNAs in the testis: building up male fertility. J Androl. 2010;31(1):26-33.

61. Pfeffer S, Zavolan M, Grässer FA, et al. Identification of virus-encoded microRNAs. Science. 2004;304(5671):734-736.

62. Bernstein E, Kim SY, Carmell MA, et al. Dicer is essential for mouse development. Nat Genet. 2003;35(3):215-217.

63. Hayashi K, Chuva de Sousa Lopes SM, Kaneda M, et al. MicroRNA biogenesis is required for mouse primordial germ cell development and spermatogenesis. PloS One. 2008;3(3):e1738.

64. Maatouk DM, Loveland KL, McManus MT, Moore K, Harfe BD. Dicer1 is required for differentiation of the mouse male germline. Biol Reprod. 2008;79(4):696-703.

65. Papaioannou MD, Pitetti JL, Ro S, et al. Sertoli cell Dicer is essential for spermatogenesis in mice. Dev Biol. 2009;326(1):250-259. 
66. Ogbuewu IP, Unamba-Oparah IC, Odoemenam VU, Etuk IF, Okoli IC. The potentiality of medicinal plants as the source of new contraceptive principles in males. NAm J Med Sci. 2011;3(6):255-263.

67. Zatuchni GI, Osborn CK. Gossypol: a possible male antifertility agent. Report of a workshop. Res Front Fertil Regul. 1981;1(4):1-15.

68. Lopez LM, Grimes DA, Schulz KF. Nonhormonal drugs for contraception in men: a systematic review. Obstet Gynecol Surv. 2005;60(11): 746-752.

69. Setchell BP. Possible physiological bases for contraceptive techniques in the male. Hum Reprod. 1994;9(6):1081-1087.

70. Liu YX. Temperature control of spermatogenesis and prospect of male contraception. Front Biosci (Schol Ed). 2010;2:730-755.

71. United Nations Population Fund (UNFPA). By Choice, Not by Chance: Family Planning, Human Rights and Development; UNFPA State of World Population 2012. New York, NY: UNFPA; 2012.

72. Cummings DE, Bremner WJ. Prospects for new hormonal male contraceptives. Endocrinol Metab Clin North Am. 1994;23(4):893-922.

73. Population Division of the United Nations Department of Economic and Social Affairs. World Contraceptive Use 2011. New York, NY: United Nations; 2011.

74. Ringheim K. Male involvement and contraceptive methods for men: present and future. Soc Change. 1996;26(3-4):88-99.

75. Wang C, Swerdloff RS. Hormonal approaches to male contraception. Current Opinion in Urology. Nov 2010;20(6):520-524.

76. Heinemann K, Saad F, Wiesemes M, White S, Heinemann L. Attitudes toward male fertility control: results of a multinational survey on four continents. Hum Reprod. 2005;20(2):549-556.

77. Moyo S, Zvoushe A, Rusinga O. Factors affecting the use of maleoriented contraceptives: a case study of the Mukarati community, Zimbabwe. Open Access Journal of Contraception. 2012;3:37-48.

78. Nieschlag E, Vorona E, Wenk M, Hemker AK, Kamischke A, Zitzmann M. Hormonal male contraception in men with normal and subnormal semen parameters. Int J Androl. 2011;34(6):556-567.

79. Primakoff P, Lathrop W, Woolman L, Cowan A, Myles D. Fully effective contraception in male and female guinea pigs immunized with the sperm protein PH-20. Nature. 1988;335(6190):543-546.
80. Herr JC, Flickinger CJ, Homyk M, Klotz K, John E. Biochemical and morphological characterization of the intra-acrosomal antigen SP-10 from human sperm. Biol Reprod. 1990;42(1):181-193.

81. Alexander N. Scientists isolate key sperm protein; finding could lead to birth control drug. Sun. 1995:3A

82. Vidaeus CM, von Kapp-Herr C, Golden WL, Eddy RL, Shows TB, Herr JC. Human fertilin beta: identification, characterization, and chromosomal mapping of an ADAM gene family member. Mol Reprod Dev. 1997;46(3):363-369.

83. Lea IA, van Lierop MJC, Widgren EE, et al. A chimeric sperm peptide induces antibodies and strain-specific reversible infertility in mice. Biol Reprod. 1998;59(3):527-536.

84. Diekman AB, Norton EJ, Westbrook VA, Klotz KL, Naaby-Hansen S, Herr JC. Anti-sperm antibodies from infertile patients and their cognate sperm antigens: a review. Identity between SAGA-1, the H6-3C4 antigen, and CD52. Am J Reprod Immunol. 2000;43(3):134-143.

85. Howes L, Jones R. Interactions between zona pellucida glycoproteins and sperm proacrosin/acrosin during fertilization. $J$ Reprod Immunol. 2002;53(1-2):181-192.

86. Jagadish N, Rana R, Mishra D, Garg M, Selvi R, Suri A. Characterization of immune response in mice to plasmid DNA encoding human sperm associated antigen 9 (SPAG9). Vaccine. 2006;24(17):3695-3703.

87. Xu B, Copolla M, Herr JC, Timko MP. Expression of a recombinant human sperm-agglutinating mini-antibody in tobacco (Nicotiana tabacum L). Soc Reprod Fertil Suppl. 2007;63:465-477.

88. Wang M, Lv Z, Shi J, Hu Y, Xu C. Immunocontraceptive potential of the Ig-like domain of Izumo. Mol Reprod Dev. 2009;76(8):794-801.

89. Lv ZM, Wang M, Xu C. Antifertility characteristics of the N-terminal region of mouse equatorial segment protein. Anat Rec (Hoboken). 2010; 293(1):171-181.

90. Hildebrand MS, Avenarius MR, Fellous M, et al. Genetic male infertility and mutation of CATSPER ion channels. Eur J Hum Genet. 2010; 18(11):1178-1184.

91. Gupta GS. LDH-C4: a target with therapeutic potential for cancer and contraception. Mol Cell Biochem. 2012;371(1-2):115-127.
Open Access Journal of Contraception

\section{Publish your work in this journal}

Open Access Journal of Contraception is an international, peerreviewed, open access, online journal, publishing original research, reports, reviews and commentaries on all areas of contraception. In addition to clinical research, demographics and health-related aspects, the journal welcomes new findings in animal and preclinical studies

\section{Dovepress}

relating to understanding the biological mechanisms and practical development of new contraceptive agents. The manuscript management system is completely online and includes a very quick and fair peer-review system. Visit http://www.dovepress.com/testimonials.php to read real quotes from published authors. 